Reproduced by kind permission of Hurst Publishers from Mohamed Zayani and Suzi Mirgani (eds), Bullets and Bulletins: Media and Politics in the Wake of the Arab Spring, London: Hurst Publishers, 2016.

\author{
FRAMING POLITICAL ISLAM \\ MEDIA TROPES AND POWER STRUGGLES \\ IN REVOLUTIONARY EGYPT
}

Abeer AlNajjar

Over the course of the Arab uprisings, Arab news media has been a central arena for political conflict in which regional rivals eagerly compete to influence public perception and opinion. Increasingly, various political antagonists struggle over access to media outlets and content in order to shape the ways in which certain events are understood by a divided public. This chapter examines the political contestation of mainstream media frames in times of political conflict. It looks at the ways in which the framing of events in both Egyptian and transnational media organizations has been contested by various state and non-state political and media actors in Egypt and beyond. Particularly, it focuses on the framing of actions taken by and against the Muslim Brotherhood in Egypt during the eventful summer of 2013. Through the use of different frames, news media contributes to the legitimization of actors and actions in certain political contexts. Of particular interest are the ways in which the use of language and visuals in Arab news coverage helped contribute to the construction of a 'terrorism' frame for Muslim Brotherhood activi- 


\section{BULLETS AND BULLETINS}

ties, which worked to delegitimize the group and to justify state violence against them.

Following the Egyptian uprising of 2011, various Islamist groups were able to have a legitimate political presence and representation. The Muslim Brotherhood in particular moved from the margins to the limelight of the Egyptian political scene. For decades, the group focused its efforts on social, medical, and educational services that became the basis for its grassroots popularity. On 6 June 2011, the group's political arm, Hizb Al Hurriyah wal 'Adala (Justice and Freedom Party), was officially established, ${ }^{1}$ and won 47.2 percent in the People's Assembly elections on 20 January 2012. ${ }^{2}$ In May of the same year, the Muslim Brotherhood's presidential candidate, Mohamed Morsi, gained nearly 51 percent of the vote in the presidential elections to become the first Islamist party candidate elected as a head of state in an Arab country and the first civil president of Egypt since 1952. His successful campaign for the presidency was a 'symbolic triumph' over Egypt's long-ruling 'military generals. ${ }^{\text {'3 }}$

This sense of triumph did not last long. The group's ascension to power was met with a wave of discontent among the Egyptian public against the rule of Morsi, in particular, and the Muslim Brotherhood, in general. A group of young activists called Tamarod, or 'rebellion', launched a campaign in April 2013 to signal a withdrawal of popular confidence in Morsi, and called for an early presidential election. ${ }^{4}$ The aim of the campaign was to gather fifteen million signatures, which they hoped to present to the constitutional court on 30 June 2013, as a non-confidence vote. The campaign was declared a success by anti-Morsi demonstrators who were supported by many oppositional political actors like the 6 April Movement and the National Salvation Front in Egypt. In response, the Muslim Brotherhood and its followers launched their own campaign on the same day at the Rabaa al-Adawiya and Nahda squares in support of the president. Pro- and anti-Morsi demonstrations continued for days. The unfolding events complicated the situation further. On 3 July 2013, the elected president was overthrown by the military under the leadership of the Defence Minister General Abdel Fattah el-Sisi. A roadmap for political transition was presented to the people of Egypt, and the head of the Constitutional Court, Adly Mansour, was appointed as an interim president. AntiMorsi protestors celebrated the move as a victory of the will of the Egyptian people. Meanwhile, Morsi supporters intensified their protests in the Rabaa al-Adawiya and Nahda squares, turning these public spaces into encampments until they were forcefully removed on 14 August 2013. In May 2014, General el-Sisi was elected president of Egypt, only a few weeks after submitting his 
resignation from the position of Chief of the Egyptian Armed Forces. Mohamed Morsi was sentenced to twenty years in prison after being convicted of ordering the murder of protesters in Al-Etihadiya in December 2012. ${ }^{5}$

This chapter investigates the political and media contestations over the meaning of two major events. The first was the ousting of President Morsi, and the events that followed, particularly the violent interaction between the Egyptian military and security forces, on the one hand, and Muslim Brotherhood members and their supporters, on the other. The second event was the violent evacuation of the Rabaa al-Adawiya and Nahda encampments on 14 August 2013. Beginning with a theoretical understanding of the role of framing in political conflict, this chapter examines framing as a process that is highly dependent on the interaction between politicians and the media. The chapter then sheds light on the framing of political Islam in the media, especially as it relates to positive or negative representations of the Muslim Brotherhood and their opposition. The Egyptian media scene and the Arab news media are discussed as the context against which media polarization is apparent in the frames selected by several media channels. Finally, the chapter explores the ways in which the various media reported the events, and examines the efforts exerted by politicians to wield influence over media content in their attempt to win public sympathy and legitimize their actions. ${ }^{6}$

\section{Framing as a Political Leverage}

In political news, framing is largely an exercise of the political elite who inform and influence media coverage, aiming to steer the public conversation on important national issues, ${ }^{7}$ including new legislation, policy changes, and action by the government. Frames organize and prioritize the presentation of facts, events, and views within a news story as an enactment of power and an instrument in the attribution of legitimacy. ${ }^{8}$ The analysis of frames is important in demonstrating how an audience's understanding and judgment of subject matters are shaped. ${ }^{9}$

The literature on news framing points to multiple effects both on the societal level-for instance, shaping public opinion regarding debatable issuesand on the individual and cognitive level. ${ }^{10}$ Broadly speaking, there are four arenas for studying frames: the sender, the message, the receiver, and the culture or context. ${ }^{11}$ Research on news framing aims at the identification of 'thematic units' (frames) in news stories; the study of the circumstances leading to the formation of certain news frames; and the understanding of an 


\section{BULLETS AND BULLETINS}

individual's interpretational power of frames and the social impact of framing, particularly on public opinion, policy decisions, and public dialogue. ${ }^{12}$ Because news frames are 'causes that shape various levels of [social] reality,'13 framing in political communication tends to be 'defined and operationalized on the basis of this social constructivism' of reality. ${ }^{14}$

Various depictions of social reality are created by the framing forces of selection and organization of information provided by the news media and influenced by concerned political actors. Framing in news media 'entails selecting and highlighting some facets of events or issues, and making connections among them so as to promote a particular interpretation, evaluation, and/or solution. ${ }^{15}$ Selection is common in various elements of a news story including language, pictures, and camera locations of the news media and their reporters. Although selection is directly exercised by journalists and news editors, it is a feature of the overarching political structure and is highly influenced by news sources and by the political actors quoted in any given news story who are keen to project certain interpretations. As the events of the Arab revolts suggest, this is especially the case during times of conflict.

Political actors attempt to influence the media's selection of words and images in any given story as an exercise of control over the creation of the social meaning attributed to the event covered. Robert Entman argues that 'successful political communication requires the framing of events, issues, and actors in ways that promote perceptions and interpretations that benefit one side while hindering the other. ${ }^{16}$ Certain framing of political conflict entails a distribution of roles amongst political opponents. The very construction of a frame details a particular understanding of a certain event or issue which offers an elaborate account of the issue definition, cause, consequence, and blame. As a form of interpretation, framing outlines remedies for the issues at hand, identifies those responsible for the wrongdoing, and gives a particular angle on the story. Naturally, parties responsible for wrongdoing tend to receive lower moral legitimacy. Authorities are keen on gaining media attention in order to exert control on media frames, on designation of blame, guilt, responsibility, and eventually on the legitimacy of actors and actions. In the case of Egypt, the legal status and political rights of the Muslim Brotherhood were targeted by the opposition and by the political elite and the military, who sought to frame them as an outlawed group that uses violence for political gain.

News media has considerable influence on the 'political standing' of antagonists. Political standing, as Gadi Wolfsfeld explains, 'refers to the relative level of political status and power of the two rivals. This type of influence can 
have a dramatic impact on the balance of power among antagonists. ${ }^{17}$ In many cases, news media can bestow the standing of 'serious political player' on designated actors by virtue of introducing them as such. ${ }^{18}$ In a cycle of political and media success, 'political standing' empowers political elites, but it also adds 'pressure on the authorities to make some type of response to challenger demands. ${ }^{19}$ The ultimate gain from raising the political standing of a certain group is the rise in the prospect of 'third-party intervention. ${ }^{20}$ In the case at hand, in their public statements, both pro and anti-Morsi camps sought to garner international support, particularly from the United States. The Egyptian military has strong ties with the United States, and has been the recipient of annual US aid since the Camp David Peace Agreement with Israel was signed in 1979. ${ }^{21}$ Before Morsi was ousted, the Muslim Brotherhood was viewed by the West as a moderate and legitimate political player. ${ }^{22}$

\section{Political Struggle over Media and Public Support}

The rule of the Muslim Brotherhood and the Freedom and Justice Party lasted for only a few months. In the summer of 2013, their status shifted from being in charge of government, presidency, and parliament to being a banned nonstate political group labelled as 'terrorists' by the military-instituted government. On 24 July 2013, army chief General Abdel Fattah el-Sisi called upon the Egyptian people to support him in his mission to confront the Muslim Brotherhood's 'violence and terrorism. ${ }^{23} \mathrm{He}$ reported that the leaders of the Muslim Brotherhood threatened that if President Morsi was ousted, a wave of violence would erupt in Egypt. He then called on Egyptians to rally around the military institution and support it in the face of possible 'violence and terrorism. ${ }^{24}$ The anti-Morsi group, Tamarod, also posted a plea to all Egyptian people to support the army in its coming war on terrorism. ${ }^{25}$ In the midst of mounting tension between the military and the Muslim Brotherhood, a spokesman of the newly appointed government condemned an attack on a police station in Mansoura, in the north of Cairo, as a 'terrorist attack.'26 Supporters of the Muslim Brotherhood accused government and military officials of plotting the attack as a conspiracy to persecute their leaders. ${ }^{27}$ The group's leaders were persecuted and sentenced either to death or life imprisonment. The Muslim Brotherhood's Supreme Guide, Mohammad Badie, was sentenced to death in March 2014 along with thirty-six other leading figures who 'were found guilty of planning attacks against the state.28

In the aftermath of the ouster of Morsi, the political scene in Egypt was polarized. Muslim Brotherhood leaders and supporters demanded the rein- 


\section{BULLETS AND BULLETINS}

statement of their democratically elected president, while Tamarod, the National Salvation Front, the military, the security forces, and the newlyappointed government pledged that there would be no return to Muslim Brotherhood rule. As was to be expected, the media was the site for heated debates amongst politicians and commentators from the two political divisions who disputed not only the actions taken by their rivals, but also particular media coverage and framing of the unfolding events. The ousting of Morsi and the events that followed split Egyptian society, but also polarized the media. There was a discrepancy between the media coverage of regional networks supporting the Muslim Brotherhood-like the Al Jazeera Arabic news channel (AJA), Al Jazeera Mubasher (AJM), and Al Jazeera Mubashir Misr (AJMM) - and those supporting the opposition-like Al Arabiya (ARA), Sky News Arabia (SNA), Capital Broadcasting Center (CBC), Al Hayat, Dream TV, and ONTV. ${ }^{29}$ The ousting of Morsi was portrayed as a 'military coup' by media outlets that were sympathetic to the Muslim Brotherhood, while it was hailed as a 'second revolution' by the anti-Morsi media camp. In their selection of images, language, and news sources, each of these channels privileged one frame over the other.

Media coverage of the summer 2013 events in Egypt was fodder for many articles published in the Egyptian media and beyond. The power political players have over media content is evident in the following three events. The first pertains to the disagreement on the number of protestors during the early days of the anti-Morsi demonstrations; ${ }^{30}$ the second revolves around pan-Arab media coverage of the ouster of the president on 3 July 2013; and the third focuses on media coverage of the violent dispersing of the Rabaa al-Adawiya and Nahda sit-ins on 14 August 2013, as covered by the Egyptian media.

\section{Framing Political Islam}

Political Islam has been one of the most influential and popular political ideologies in the Middle East over the past few decades. The most notable examples are the Saudi Salafist movement and the Muslim Brotherhood, which emerged in Egypt in 1928 and has supporters in many countries of the region and beyond as it turned into a transnational organization. Political Islam is increasingly becoming an umbrella for many diverse groups who differ in 'their approach to major themes such as the nature of society, the preferred relationship between Islamist activists and the political system, methodology for alleviating socioeconomic frustrations and spiritual laxity, and the tempo- 
ral framework within which Islamist goals are to be achieved. ${ }^{31}$ These variations make it even more challenging to discuss political Islam and to draw any conclusions regarding these groups' political roles and strategies in the various contexts in which they exist and operate.

The legitimate status of political Islam is evident in its role in the emergence of political parties in countries like Jordan and Kuwait, where formations of this political current have been an important political player whose representatives have participated in parliaments for many years. Many observers predicted that the Muslim Brotherhood in Egypt would follow suit and adapt to the country's new political reality. This adaptation entails the presence of a will to change the group's 'public discourse' and its role in the public sphere. ${ }^{32}$ Meanwhile, the new political environment fostered an accelerated pace of regional attempts to extend and expand political and ideological influence through shifting, retaining, and strengthening old and new alliances with these religious groups.

Since its formation, the Muslim Brotherhood has experienced ambivalent relations with the Egyptian state. Although, since the 1970s, the group denounced violence, and mobilized its efforts in social, media, and educational services, ${ }^{33}$ it was still not permitted to be a political player and was suppressed by Hosni Mubarak's regime. ${ }^{34}$ With the fall of Mubarak, the group's status shifted from being legally banned to being a legitimate political player that won elections and came to office. The group is generally viewed as moderate for 'call[ing] for gradual change that is to be undertaken from within the political system and with the enlistment of the Muslim masses. ${ }^{35}$ Therefore, accommodating the Muslim Brotherhood's movements and political affiliates, especially in Egypt, has long been advocated by political commentators and foreign policy advisors as a way of neutralizing and combating extremist Islamic ideology, ${ }^{36}$ in particular the likes of Al-Gama'a Al-Islamiya, an Islamist group that used violence against foreigners and tourists during the 1990s in Egypt.

\section{The Politics of Egyptian Media}

In Egypt, media and politics are intrinsically interdependent. For many decades, especially during the Gamal Abdel Nasser era of 1952-1970, media was highly monitored and regulated by the Egyptian army. Millions across the Arab region tuned in to Sawt $\mathrm{Al} \mathrm{Arab,} \mathrm{the} \mathrm{Voice} \mathrm{of} \mathrm{the} \mathrm{Arabs} \mathrm{radio} \mathrm{station,} \mathrm{to} \mathrm{learn} \mathrm{about}$ Nasser's 'anti-colonialist,' secular, and pan-Arab ideology. ${ }^{37}$ Despite relaxation of 


\section{BULLETS AND BULLETINS}

restrictions on freedom of the press sanctioned by Nasser, President Sadat often reverted to imposing other constraints during his rule (1970-1981).$^{38}$ Likewise, despite the privatization of the media sector and the growth of satellite television channels in Egypt during President Mubarak's era, journalists were still subject to harassment, arrests, and physical violence. ${ }^{39}$ Yet, 'new spaces of expression emerged within enduring systems of authority, surveillance and state control. ${ }^{40}$ During the Mubarak regime, essentially, privately owned media 'operated within limits' and rarely crossed 'red lines. ${ }^{211}$ When red lines were crossed, outspoken journalists faced persecution and imprisonment.

Several scholars captured the disjuncture between the development of media, on the one hand, and undemocratic practices, on the other, during the last few years of Mubarak's era. ${ }^{42}$ There was a notable incompatibility between the growing outspoken, showy, and somewhat critical media and the stalled democratic processes and practices in the country. ${ }^{43}$ The reluctance of regimes to allow people to speak and vent at the expense of their political and economic rights is well recognized as a state mechanism to safeguard the political status quo. ${ }^{44} \mathrm{~A}$ similar disjuncture can be seen in the relationship between the press and the public as the illiteracy rates in Egypt are still relatively high. ${ }^{45}$ Equally noteworthy is that the language used in the press is different from that used by common men and women, as the press uses the formal modern standard Arabic and the public use the Egyptian vernacular to communicate. ${ }^{46}$ This is not the case with broadcast media. Television is considered a more attractive medium for audiences with its pictorial content, various sound and visual effects, and the appeal of the Egyptian colloquial dialect used by television anchors and presenters on many of the Egyptian channels.

The independence of Egyptian media both public and private was oftentimes questioned by media observers and journalists alike. Editors-in-chief of major semi-official newspapers were appointed by the Speaker of the House of Representatives during Mubarak's reign. The Shura Council, the upper House of Parliament, continued to appoint editors of these papers after the 2011 revolution, and the Council 'was a front for the presidential office. ${ }^{37}$ Hence, the Egyptian mainstream media played an ambivalent role during the 2011 uprisings, and initially hesitated to frame the 25 January 2011 protests as a 'revolution.' Semi-official newspapers, including $\mathrm{Al}$ Abram, $\mathrm{Al} A \mathrm{Akb} b a r, \mathrm{Al}$ Jumboriya, and $A l$ Messa, framed the protests as a conspiracy. ${ }^{48}$ Portraying the protests as a threat, the media frequently 'constructed frames based on unverified assertions as to what was happening.' ${ }^{49}$

During the summer and winter of 2013, many commentators and analysts blamed Egyptian media for dividing and polarizing the public, turning the 
Egyptian street into a 'battle ground. ${ }^{50}$ Media outlets were accused of siding with either the Muslim Brotherhood or the military and its new political alliance. Mohamed Al Jawadi argues that it was inevitable for Egyptian media to side with the 'coup leadership' due to issues of 'ownership and inherited loyalties. ${ }^{51}$ On the whole, media owners in Egypt are not particularly interested in the improvement of the media, in cultivating the professional standards of their outlets, or in challenging the regime. Rather, their attention is directed at serving their own interests and the government in power. ${ }^{52}$ Joshua Hersh quotes Fatima el Issawi as saying that 'one problem that can't be overlooked is how little the [Egyptian] media evolved during the Morsi era. ${ }^{53}$ Hence, during the ousting of Morsi and the subsequent events of 2013, the media in Egypt were seen as amplifying the crisis in the country, making it impossible for the government and military to run any political negotiations with the Muslim Brotherhood. ${ }^{54}$ Overall, the networks created an increasingly polarized and hostile media environment. 55 Their failure to play a constructive role in the crisis and to uphold ethical journalistic practices were attributed to a state of confusion' resulting from the fact that Egyptian journalists were not expected to think and act independently in the pre-2011 media environment. ${ }^{56}$

In the summer of 2013, the military paid great attention to media and its role in influencing public opinion. The military-backed Egyptian government took four television channels off air immediately after the ousting of Morsi. In addition to the official Muslim Brotherhood channel Misr 25, other channels supportive of the Muslim Brotherhood including Al Hafez, Al-Nas, and the Salafist ArRahma were shut down. At the same time, the military sought to enhance its own media presence and influence. Ahrar $25 \mathrm{TV}$ was launched in mid-July 2013 to substitute the Muslim Brotherhood channel Misr 25. ${ }^{57}$ During the early days of July 2013, the military was present in the offices of all semi-official Egyptian media and even in newsrooms to guarantee favorable coverage of the military announcement and its actions. ${ }^{58}$ After ousting Morsi and before evacuating the pro-Muslim Brotherhood protestors from the Rabaa al-Adawiya and Nahda encampments, an appeal for support was made public by the chief of the Egyptian army, Abdel Fattah el-Sisi.

In the following days, the police searched the offices of Muslim Brotherhood newspapers in Egypt in response to a 3 September 2013 court decision banning the Muslim Brotherhood and ordering the seizure of its property, a decision of a political nature. ${ }^{59}$ Both the appointed government and Muslim Brotherhood supporters targeted journalists. ${ }^{60}$ In early September 2013, Reporters without Borders stated that since the ousting of Morsi, 'a total of 


\section{BULLETS AND BULLETINS}

five journalists have been killed, eighty journalists have been arbitrarily detained (with seven still held) and at least forty news providers have been physically attacked by the police or by pro-Morsi or pro-army demonstrators. ${ }^{31}$ Journalists and media channels assumed a central role in the conflict generated by the two opposing political camps and their supporters. In the wake of the uprisings, Egyptian journalists are still experiencing exploitation, self-censorship, and uncertainty under the military-backed government. ${ }^{62}$

In January 2015, in a leaked recording from el-Sisi's office, the Chief of Staff Abbas Kamel, can be heard instructing the military spokesperson, Ahmad Ali, to call up a few influential TV personalities and provide them with statements to make on air to rally support for the military and the president. ${ }^{63}$ Since the appointment of el-Sisi, criticism of the president or the regime has hardly ever been voiced in the Egyptian media. Even Al Bernameg, Bassem Youssef's critical satirical show, ${ }^{64}$ was initially shut down twice by the Egyptian TV network Capital Broadcasting Center (CBC) allegedly for contract related issues. The show appeared for a few months in 2014 on the screen of a regional broadcaster, the Middle East Broadcasting Corporation (MBC), and then was stopped by the host himself shortly before the ascension of el-Sisi to the presidency, due to what Youssef perceived as the 'unsuitable climate in Egypt' and for reasons of personal safety as well as that of his family. ${ }^{65}$ Youssef rarely criticized el-Sisi, although he often criticized and mocked Morsi during his presidency.

Since the ousting of Morsi, there has been a noted deterioration in ethical standards in Egyptian media. A number of prominent Egyptian editors and journalists reported that the independent media found themselves drifting into a new role' playing side by side with the semi-official media, the military, the judiciary, and the police. ${ }^{66}$ They noted that 'notions of ethical, independent journalism were suspended and replaced by self-censorship and partisan reporting. ${ }^{67}$ This was at the time when the Muslim Brotherhood were persecuted and delegitimized by the military backed government as a 'terrorist' organization. ${ }^{68}$

\section{Pan-Arab Media on the Frontline}

Egyptian media suffered state censorship and interference and the pan-Arab news channels were subject to political pressure, polarization, and alignments. A number of pan-Arab channels were also denounced over their coverage of Egypt's political crisis during the summer of 2013. Both Al Jazeera and Al Arabiya were criticized by Ahram Online for echoing the 'opinions of their 
financiers' Qatar and Saudi Arabia, respectively, who were competing for regional influence over the countries of the Arab uprisings. ${ }^{69}$ Qatar is considered to be a patron of the Muslim Brotherhood and Morsi in Egypt, while the Kingdom of Saudi Arabia lent its support to el-Sisi and pledged five billion dollars in support of the military-backed government in Egypt and its effort to battle 'terrorism and extremism.' ${ }^{70}$

Al Jazeera Arabic, known internationally for crossing the red lines of Arab news and political taboos, was accused of committing 'frequent violations that are incompatible with any code of journalistic conduct, and which amount to incitement to violence and hatred, if not to murder. ${ }^{31}$ In July 2013, a number of $\mathrm{Al}$ Jazeera personnel in Egypt were reported to have resigned from the channel 'in protest of the network's coverage of events there. ${ }^{12}$ After the military's dispersal of the pro-Morsi sit-ins in August 2013, even Al Jazeera English was perceived as not fully abiding by professional journalism standards, following in the footsteps of Mubasher Misr in its 'partisanship' and 'one-sided' reporting of Egypt's crisis. ${ }^{73}$

Not surprisingly, the military backed government sought to rein in $\mathrm{Al}$ Jazeera. A few hours after Morsi was overthrown, Al Jazeera Mubasher's broadcast was interrupted, its office was raided, and some of its journalists were arrested by Egyptian security forces. ${ }^{74}$ Subsequently, on 25 August 2013, the channel was declared 'illegal' by the Ministry of Communications and Information Technology. ${ }^{75} \mathrm{~A}$ few weeks later, four journalists from $\mathrm{Al}$ Jazeera English were expelled from Egypt for an alleged lack of 'correct press accreditation. ${ }^{76}$ In December 2013, another three staff members of Al Jazeera were arrested by the Egyptian security on 'suspicion of using unlicensed equipment, broadcasting false news and possessing fake footage. ${ }^{77}$ State-run Egyptian media reported that Al Jazeera was 'distorting Egypt's image abroad, damaging its political standing, and making the international public believe that the unreal footage showed what was happening in Egypt and that the country was witnessing a civil war. ${ }^{78}$ The detained Al Jazeera journalists were tried multiple times, and were eventually freed. ${ }^{79}$ Sixteen more foreign journalists were arrested during the same period, which made Cairo 'a threatening and hostile place' for foreign journalists. ${ }^{80}$

As the el-Sisi regime grew anxious over its image, it extended restrictions and intimidation against both national and pan-Arab journalists and media outlets. In order to regain control, it was important for the military-backed government to silence Morsi's supporters in the media, including Al Jazeera. The government's measure of silencing the media reached channels beyond its 


\section{BULLETS AND BULLETINS}

juridical and executive powers like AlYarmouk TV, broadcasting from Jordan and affiliated with the Muslim Brotherhood there, and AlQuds TV, which was affiliated with the Palestinian Islamic resistance organization Hamas. Turkish channels were also targeted, their offices raided, and one of their journalists detained for more than two weeks. ${ }^{81}$ Major international news outlets like the $\mathrm{BBC}, \mathrm{CNN}$, and The Guardian were accused of falling short of providing balanced coverage of the events in Egypt and of displaying inadequate understanding of the situation in Egypt. ${ }^{82}$

\section{Media Framing of the Ousting of Morsi}

Political division and contestation over media representations began long before the military ouster of President Morsi. ${ }^{83}$ As many political players in the region grew wary of the implications of empowered Islamist voices in the emerging public sphere, ${ }^{84}$ several media channels in Egypt were critical of the Muslim Brotherhood and its political leadership. The latter were depicted as inefficient, corrupt, fundamentalist, focused on power grabbing, and exclusionary. ${ }^{85}$ As would be expected, religious channels backed Morsi and the Muslim Brotherhood government and accused the opposition of being conspirators, ${ }^{86}$ corrupt, counter-revolutionary, and remnants of the Mubarak regime.

Egyptian TV channels, religious and otherwise, contributed to both the media and political polarization that began during the January 2011 uprisings. After the military and interim government began closing down religious channels and silencing Muslim Brotherhood supporters, few channels cared to represent the views of the Muslim Brotherhood, and many of those that did were non-Egyptian. ${ }^{87}$ Fewer were those channels that reported the Egyptian crisis adequately by offering a non-opinionated and balanced treatment.

Ideally, balance in news media implies representing at least two interpretations of an issue that allow for the articulation of competing views in order to facilitate an informed public dialogue. In framing theory, balance as a journalistic principle is pronounced in the concept of 'frame parity,' which necessitates access to at least two equally treated frames or interpretations of a certain contested event, issue, or person. ${ }^{88}$ This was not the case with the political developments in Egypt. The end of the Muslim Brotherhood's rule was highly contested in the news media, and was portrayed as either a 'second revolution' or as a 'military coup.'

The ouster of President Morsi was understood and communicated by the military and oppositional sources as a 'second revolution' in reference to the 
25 January 2011 uprisings, shedding a positive light on events. In this frame, the people of Egypt protested against President Morsi in 2013 as they did against former President Mubarak in 2011. Hence, the military intervention in 2013 was represented as being similar to its intervention against Mubarak and in support of the protesting public two years earlier. In both cases, the military was perceived as having stood behind the people. The military support of the anti-Morsi opposition was represented as protecting the country from civil war and assisting the Egyptian people in articulating their political will. According to this frame, the army was the savior of the people, and an instrument of the popular will of Egyptians.

Contrary to the 'second revolution' frame, the 'military coup' frame views the action of the military as an attack on the 'first democratically elected president' of Egypt and a moment of rupture in the incipient democratic system. Hence, the military was perceived as having caused a political crisis and ruptured the early phase of building a democratic system. With the noted exception of $\mathrm{Al}$ Jazeera, during the three days leading up to the ouster of Morsi, and immediately thereafter, Egyptian TV channels and pan-Arab media outlets, such as Al Arabiya and Sky News Arabia, leaned towards the 'second revolution' frame in their coverage. Such framing induced public reactions; an Al Jazeera crew was reported to have been pushed out of Tahrir Square, while an Al Arabiya crew was asked to leave Rabaa Square by the pro-Morsi protestors. ${ }^{89}$

The location of cameras-whether in Tahrir Square where anti-Morsi demonstrations were stationed, or in Rabaa Square where pro-Morsi protestors were located-helps the construction of certain aspects of social reality at the same time that it ignores others. In addition, the images taken by media cameras from the same square were also markedly different. On the first day of anti- and pro-Morsi protests in the Rabaa al-Adawiya area, the Al Arabiya and Sky News Arabia cameras were broadcasting images of protestors carrying sticks and preparing to take up a fight, while Al Jazeera selected images of ordinary men, women, and children chanting pro-Morsi slogans..$^{90} \mathrm{On} \mathrm{Al}$ Jazeera, the pro-Morsi protesters appeared as everyday people voicing their support, but on the Al Arabiya network, they were presented as a violent group of people. Evidently, these images projected different social realities and defined issues differently.

The framing of these events in Egypt was not limited to language; images and visuals were also instrumental in the process of meaning construction. The dominant image on some channels was that of large numbers of anti-Morsi protestors. ${ }^{91}$ Throughout the coverage of events in Egypt in the days after 


\section{BULLETS AND BULLETINS}

30 June 2013, Al Jazeera showed a life-size image of Morsi on the video wall in the background behind the presenters during its news bulletins, ${ }^{92}$ an image that was intended to serve as a constant reminder of President Morsi. The presence of the image as well as its size and location at the center of the screen were conscious editorial decisions that symbolized the resilient presence of a president whose legitimacy was disputed in the Egyptian streets. The image projected the president's authority and legal position, suggesting that the solution to the crisis was to reinstate the 'legitimate' president.

Since selection and salience are important features of a news frame, ${ }^{93}$ the strategy of visualization and titling decisions to influence the audience requires close examination. For Al Jazeera, Morsi's image was more salient in size, location, and color than the image of large numbers of protesters in Tahrir and Etihadiya. Cognizant that 'framing shapes public dialogues about political issues, ${ }^{94} \mathrm{Al}$ Jazeera attempted to bring Morsi back to the attention of viewers through his dominant onscreen presence. Conversely, the competing channel, $\mathrm{Al}$ Arabiya, focused on protests in various locations in Cairo such as the Tahrir and Etihadiya areas, but also on other Egyptian cities such as Alexandria and Port Said. Al Arabiyass screen was divided among these four locations in addition to showing various images from Rabaa Square, the location of the pro-Morsi protestors. ${ }^{95}$ Although the two channels covered the same events in Egypt, each defined the problem differently.

The 'military coup' frame is potentially consequential in its ability to undermine the legitimacy of the appointed interim Egyptian government and delegitimize its actions. Egyptian media framing also attempts to influence the international community, especially the United States and European Union. The military-backed Egyptian government and president faced an immensely sympathetic media environment in Egypt, but a relatively cynical, if not hostile, media environment on the international front. International media sources such as BBC World adopted the 'military coup' frame to portray the ouster of Morsi, and were not persuaded by the 'second revolution' frame. The phrase 'military coup' was used by the Daily Telegraph, CNN, and ABC News. ${ }^{96}$ Similarly, reports from The Washington Post and New York Times International included quotes and questions in which the phrase 'military coup' was used. ${ }^{97}$

On the political front, European and US officials were initially hesitant to show any direct support of either political camp, and President Obama was criticized by the US media for not using the word 'coup.' The official US position and public statement is important considering that the United States pro- 
vides $\$ 1.5$ billion a year in aid to Egypt; much of which benefits the military that overthrew Morsi. An alarming development loomed on the political horizon as the Obama administration considered which measures to take towards the Egyptian military, ${ }^{98}$ since US law stipulates that the US government should cut off aid to any country in the event that an elected head of government is deposed by a military coup d'état or decree. ${ }^{99}$ Many analysts expected a cut in US aid to Egypt and a halt in military deals..$^{100}$ Hence, as a response to mounting international pressure and opposing media coverage, criticism, and unsympathetic representations, the Egyptian government hired a US lobbying firm, Glover Park Group, to help improve its deteriorating image. ${ }^{101}$

The prominence of one frame over another largely depends on the political affiliation of the channel, where the cameras are positioned, where the correspondents are assigned, whose press conferences are covered, and who the studio guests are, among other political considerations. These editorial decisions affect the choice of words and images in news reports, use of labels, and assigning of blame. Notably, the way in which Egyptians and the world understood the ousting of President Morsi was of great concern to all parties. For the Muslim Brotherhood, this was the end of a long-awaited and hoped-for power position and official role that was vital for the political future of the group. The words 'legitimacy' and 'legitimate' were constantly emphasized in Muslim Brotherhood statements, and were repeated twenty-three times in the last speech Morsi gave a few hours before his ousting. ${ }^{102}$ Similarly, since 30 June 2013, pro-Morsi demonstrators also began using the word 'legitimacy' and related terms in their demonstrations, and displayed Morsi's image with statements like ar-ra'es ash-Sharei (the legitimate president), or naiam lesh-shareia (yes to legitimacy). ${ }^{103}$ Furthermore, Muslim Brotherhood supporters referred to the oppositional demonstrations as a 'war against democracy,' pointing out that Morsi was the 'first democratically elected president' in the long history of Egypt. Al Jazeera added the term 'civilian' to describe President Morsi, ${ }^{104}$ which is a clear reference to the more than sixty years of military rule in Egypt, and the fact that all previous Egyptian presidents came from the military.

Meanwhile, anti-Morsi demonstrators and opposition leaders frequently used terms like 'voting with their feet' or 'public protest vote' to confront the legitimacy argument. Because Morsi was the first democratically elected president, and the legitimacy argumentation was heated amongst political leaders, Tamarod and other political groups countered Morsi's presidential 'legitimacy' with the 'legitimacy' of the demonstrating public. The military did not want the world to perceive its actions as a 'military coup' nor as a renewal of the 


\section{BULLETS AND BULLETINS}

authoritarian military rule of Egypt. It advanced a 'revolutionary legitimacy' interpretation of its actions and stressed that its move was instigated and endorsed by the demonstrators.

The use of phrases like 'the Egyptian public are voting with their feet' in the early days of the demonstrations that led to the ousting of the president was embodied in the number of anti-Morsi protestors in Tahrir Square and the Etihadiya Palace area. This was used as a counterbalance to the votes that were given to Morsi at the ballot box one year earlier when he was elected as president. The term 'voting with their feet' was used by various analysts as well when describing the protests on 30 June 2013, and the days that followed. Many of the pro-Muslim Brotherhood activists and commentators referred to legitimacy, whereas Tamarod leaders and supporters referred to the significant number of signatures, about 21 million, voting the president out of office. Both pro- and anti-Muslim Brotherhood camps were keen to show that their actions were appropriate within a democratic framework. Thus, General Abdel Fattah el-Sisi claimed the legitimacy of his actions was embodied in the execution of the will and demands of the people, in addition to paving the way for a second revolution. El-Sisi sought an endorsement from the Egyptian people to 'fight terrorism, stating that the Egyptian army accepts orders only from the Egyptian people. ${ }^{105}$

The conflict over legitimacy, or lack thereof, continued to influence politicians, political rhetoric, and media coverage. During the rallies that followed, the number of anti-Morsi protesters was contested by various reporters, field sources, and political leaders of the opposition. CBC TV reported that the protests on 30 June 2013, were the 'biggest protests in human history, ${ }^{106}$ and had aerial footage that purported to show thirty-three million people in Tahrir Square. Reuters in turn quoted an unidentified military source, suggesting that the number reached thirty-three million. Meanwhile, the BBC registered the 'military coup' frame of military intervention, reporting that the ousting was a popularly-backed 'military coup—there's no two ways about it.' ${ }^{107}$

Despite the differing agendas, the contestation over the numbers of protestors from both sides came with reference to the democratic process. Since certain perceptions of the preferences of public opinion can 'help delegitimize and silence the opposition, ${ }^{108}$ both parties strived to create their own version of Egyptian public opinion. It was important for the pro-Morsi camp to adhere to the 'military coup' frame as grounds for reinstating the overthrown President Morsi. They did so as a means of popular mobilization for their objective of maintaining democratic practices and political processes, which have been highly valued on Egyptian streets since the 2011 uprisings. 
As far as public opinion is concerned, on the whole, the Egyptian people tend to view religion as an important aspect of their daily lives. ${ }^{109}$ The fact that a large sector of the Egyptian Muslim population is opposed to the Muslim Brotherhood means that many Egyptians perceive of this religious Islamic group as somehow 'deviant.' This image could result from the group's own actions and responses as much as it could be constructed through the negative portrayal of their political rivals. On a global scale, utilizing the 'terrorism' frame is a tool for anyone wishing to marginalize a political Islamic group insofar as it fits into the global view of Islamists as 'irrationally violent." ${ }^{110}$ The Muslim Brotherhood did indeed resort to violence in the past, but denounced it as a tactic in the 1970s.

\section{The Violent Evacuation of the Rabaa and Nabda Sit-ins}

The violent evacuation of Muslim Brotherhood members and their supporters from the Rabaa and Nahda encampment sit-ins on 14 August 2013 resulted in the death of hundreds of pro-Morsi supporters. The toll of casualties was highly manipulated by all parties. In the early hours of 14 August 2013, Muslim Brotherhood sources were quoted in Al Jazeera Arabic saying that the number of people killed in both encampments exceeded 300, whereas Capital Broadcast Center $(\mathrm{CBC})$ estimated the number of dead to be fifteen. ${ }^{111} \mathrm{CBC}$ reported their source to be a spokesperson from the Ministry of Health, whereas $\mathrm{Al}$ Jazeera depended on Muslim Brotherhood sources. A few days after the evacuation, the BBC reported the toll of pro-Morsi protestors and security forces to be about $850,{ }^{112}$ while Human Rights Watch reported that 'at least 278 proMorsi protestors' had died. In most media reports, there was no distinction made between Muslim Brotherhood casualties and those of state security. ${ }^{113}$

The newly appointed interim government and its political allies, the security forces, Tamarod, and the National Salvation Front, framed the Muslim Brotherhood members and their supporters as 'terrorists', and described their vocal presence on Egyptian streets as an 'act of terrorism.' To add to this representation, Al 'Ashera Masa'an, the flagship current affairs program on the Dream 2 Channel, broadcast a documentary titled 'Egyptians to save the world from terrorism. ${ }^{114}$ Similarly, the Egyptian Interior Minister, General Mohammad Ibrahim, was quoted in the Al-Masry Al-Youm newspaper describing the protestors in Rabaa and Nahda encampments as 'armed gangs. ${ }^{.115}$ Hence, the army's forceful evacuation of pro-Morsi supporters from the encampments was an act of 'fighting terrorism.' However, framing the 


\section{BULLETS AND BULLETINS}

story in a different way, $\mathrm{Al}$ Jazeera reported that supporters of Morsi were defending the legitimacy (ash-shariya) of the ousted president.

Resorting to the frame of 'terrorism' is politically significant. The frame was used by military and political sources from the opposing parties as a way of justifying the use of violence against the Muslim Brotherhood. The interpretation of news and events rests on public opinion. ${ }^{116}$ To depict Muslim Brotherhood supporters as 'terrorists' justifies state violence against them. To this effect, the Egyptian military announced that security units were being stationed in areas surrounding the demonstration to prevent potential acts of violence. ${ }^{117}$ Thus, utilizing the terrorism frame casts the accused as an outlaw group that has lost its civilian status, its claims to legitimacy, and civil rights. From the outset, military and political leaders from both the anti- and proMorsi camps expressed concern over the security of protestors, and developed it into a media issue.

In CBC, Al Hayat, and ONTV, among other Egyptian channels, 'Fighting Terrorism' and 'War on Terror' were the headlines for much of the political talk shows between 3 July 2013 and the few days following the forceful eviction of Muslim Brotherhood sit-ins. ${ }^{118}$ The 'terrorism' frame counterbalanced the 'military coup' frame adopted by the leaders and the supporters of the Muslim Brotherhood. In all demonstrations, media interviews, and public appearances, the Muslim Brotherhood leaders and supporters played out the 'legitimacy' frame. In this case, a strong identification was made with the victims, since 'media only allow for one injustice frame at a time ... in keeping with its need to tell simple stories. ${ }^{\text {'119 }}$ Hence, each particular media can represent only one of the camps as a victim.

To CBC, ONTV, Al Hayat, and Dream TV, the Egyptian people were portrayed as the victims who needed the protection of the military. In their news shows, Muslim Brotherhood supporters were portrayed as the guilty party even when they were being killed. Images of Muslim Brotherhood casualties in the forceful ejection of the Rabaa and Nahda encampments rarely appeared on Egyptian TV channels - they were dehumanized and, as such, remained faceless. These same channels gave considerable coverage to the casualties of the military, security forces, and the police. They were presented as heroes sacrificing themselves to protect the Egyptian people; their funerals were aired, and their relatives interviewed. In reaction to this orchestrated media campaign, Gehad AlHaddad, the spokesperson for the Muslim Brotherhood, wrote in The Guardian: 'General Abdel Fattah al-Sisi, leader of the coup-that's-not-a-coup, gave a speech that has to be read as paving the way for a bloody campaign of repression. ${ }^{120}$ 
Both pro- and anti-Morsi camps have not given due acknowledgement to the violence perpetrated against the opposition. While the government blamed the Muslim Brotherhood for the violence, the latter's leaders did not acknowledge the violent actions by their supporters, and the fact that there were other victims of the violent confrontations and evacuation.

\section{Conclusion}

Frames deserve attention because they can influence audiences' understanding of political issues. Framing can help steer attention towards a 'civil liberties frame' through the use of a 'free speech' value, which makes public opinion more tolerant to the rallies of public protests. ${ }^{121}$ At the same time, a 'terrorism' narrative can create intolerance amongst the public, as in the case of the Muslim Brotherhood in Egypt. As Entman points out, 'the words and images that make up the frame can be distinguished from the rest of the news by their capacity to stimulate support of or opposition to the sides in a political conflict ... Frame contests occupy the left sector of the continuum, falling somewhere between complete frame dominance and a degree of contestation. ${ }^{122}$ In other words, the coexistence of equally important, yet contested frames of the same event is rare. Oftentimes, news media offer narratives that lean towards championing one frame over another, which jeopardizes the balance of coverage and results in a 'preferred frame.'

Politicians are thus compelled to compete with each other and with journalists over news frames. For Entman, 'framing in this light plays a major role in the exertion of political power, and the frame in a news text is really the imprint of power-it registers the identity of actors or interests that competed to dominate the text.' ${ }^{123}$ The level of tolerance that the public develops for a particular group depends greatly on how their actions are framed, including the group's traits and the environment of their actions. ${ }^{124}$ As Nelson, Clawson, and Oxley point out, 'tolerance reflects not only stable characteristics of individuals and groups but also more volatile environmental factors, such as the way the mass media frames the central features of the tolerance controversy.'125

The Muslim Brotherhood protests nurtured an antagonistic atmosphere, and media coverage of the ousting of President Morsi contributed to the Egyptian public distancing themselves from their fellow Muslim Brotherhood members and sympathizers. Furthermore, the terrorism frame used by politicians and reported by the anti-Muslim Brotherhood Egyptian media paved the way for the construction of a narrative that portrayed members of the 


\section{BULLETS AND BULLETINS}

group as outlaws, if not outright 'terrorists.' This partly explains the public tolerance for the forceful evacuation of the Muslim brotherhood sit-ins and the predilection to accept violence against them as a 'legitimate' act. Considering the 'violent' nature of the group's members and their alleged disloyalty to their nation, state violence came to be seen as a necessary evil. 